\title{
Conflict of Laws: Foreign Law as Datum
}

\section{Herma Hill Kay*}

Conflict of laws ... has for a long time been eking out an existence of sorts in the courtrooms themselves, though in only a few states has it begun to have recognizable features. Then why did the plot get so thick when the mystery was so thin?t

$\mathrm{T}$ HE CONTRIBUtions of a great judge to the development of the law may be measured in many ways. In Chief Justice Traynor's case, the result is the same no matter what standard is applied. No respectable casebook dealing with state law can go to press without a Traynor opinion; top-ranking law students seeking clerkships are advised to apply to distinguished courts, like the United States Supreme Court, or to distinguislied judges, like Roger Traynor; leading law schools compete to invite him to teach at their summer sessions, to accept their honorary degrees, and to lecture at their most auspicious occasions; law journals eagerly seek to print his lectures as leading articles. ${ }^{1}$ In a Symposium sucl as this, where his many achievements are being recognized, it is perhaps presumptuous to lay claim to Traynor's primary interests. Yet his recent teaching has been devoted to conflict of laws and one of his major articles is a land-mark in conflicts theory. ${ }^{2}$ A Round Table discussion at the Association of American Law Schools 1962 Meeting lonored his contributions to conflict of laws, ${ }^{3}$ and his achievements in that area have been singled out for comment by almost every major writer in the field. Indeed, his work in conflict of laws has been reviewed in great detail by Professor Brainerd Currie. ${ }^{5}$

It is difficult to add anything to most of the cases discussed by Currie.

* B.A. 1956, Southern Methodist University, J.D. 1959, University of Chicago, Professor of Law, University of California, Berkeley.

$\dagger$ Traynor, Is This Conflict Really Necessary?, 37 Texas L. Rev. 657 (1959).

1 E.g., Traynor, No Magic Words Could Do It Justice, 49 CAIIF. L. Rev. 615 (1961).

The article was delivered as the First Annual Walter Perry Johnson Lecture on Law and Public Affairs at the University of California, Berkeley, April 22, 1961.

2 Traynor, Is This Conflict Really Necessary?, 37 Texas L. REv. 657 (1959).

3 The only other AALS Round Tables honoring the contributions of an individual to Conflict of Laws have been those devoted to the work of Currie (1958) and Ehrenzweig (1964).

4 E.g., Cavers, Oral Contracts to Provide by Will and the Choice-of-Law Process: Some Notes on Bernkrant, in Perspectives of LAW-EsSays For Austin Wakearan Scotr 38 (Pound, Griswold, Sutherland ed. 1964); Currie, Survival of Actions: Adjudication versus Automation in the Conflict of Laws, 10 STAN. L. REv. 205 (1958); EHreN2wErg, CoNfurct of Laws, passin (1962), and the Dedication of his ConfuTCrs IN a NuTsenerr (1965).

5 Currie, Jistice Traynor àid the Conflict of Laws, 13 Sran. L. REv. 719 (1961); Currie, Selected Essays on the Confutct of Laws 629 (1963) [hereinafter cited as SEIECTED ESSAYS]. 
There would be, at most, a difference in emphasis: I would have recognized in the text, rather than the footnotes, ${ }^{\circ}$ that Traynor has replaced his first tentative approach ${ }^{\gamma}$ to the forum's modification of a sister state's support decree im a later, carefully thought-out and path-breaking opinion. ${ }^{8}$ I would have given more space to Traynor's leading decision that recognized and applied the Vanderbilt ${ }^{9}$ doctrine as a matter of state law. ${ }^{10}$ But these are matters to be discussed in a letter to the author praising his earlier article, not the subject matter of a later piece. There is, however, one opmion-a dissenting opinion at that-which $I$ believe requires further analysis. In his opinion in Estate of Perkins, ${ }^{11}$ Traynor set forth what may appear at first glance to be merely a hiteral interpretation of Probate Code sections 228 and 229. The thrust of his dissent was that those sections did not control the distribution of the estate in question; the majority held that the sections applied. Currie, in rare disagreement with the result of a Traynor opinion, thought the majority was right. I think that Currie and the court were wrong and that Traynor was right; but the point is inore important than a mere difference of opinion. Traynor's dissent provides a significant insight into a comparatively neglected aspect of Currie's general approach to conflicts theory: the reference to foreign law for the purpose of finding and applying a datum point rather than a rule of decision.

I propose, first, to revisit Estate of Perkins. I shall then mention the only conflicts case that Traynor has had opportunity to write since Currie's detailed review: Bernkrant v. Fozeler. ${ }^{12}$ I shall not do more than mention Bernkrant, because it too has already been conımented on by some of the most famous nanies in American conflicts law: Cavers, ${ }^{13}$ Ehrenzweig, ${ }^{14}$ Reese, ${ }_{9}^{16}$ and, indeed, Currie, ${ }^{16}$ in a later article. Such are the footsteps on the path that must be trod by one who would comment in 1965 on a Traynor conflicts decision written in 1961.

6 Id. at 751, n.128, SELECTED EsSAYs at 662.

7 Biewend v. Biewend, 17 Cal. 2d 108, 109 P.2d 701 (1941).

8 Worthley v. Worthley, 44 Cal. 2d 465, 283 P.2d 19 (1955).

9 Vanderbilt v. Vanderbilt, 354 U.S. 416 (1957).

10 Eudson v. Hudson, 52 Cal. 2d 735, 344 P.2d 295 (1959). See Currie, supra note 5, at 759, SErected Essays at 669-70.

1121 Cal. 2d 561, 134 P.2d 231 (1943).

1255 Cal. 2d 588, 360 P.2d 906, 12 Cal. Rptr. 266 (1961). Currie, supra note 5, at 778 n.236, Setreted Essays at 688-89.

13 Supra note 4.

14 Supra note 4, at 475 n.37.

15 Reese, Confict of Laws and the Restatement Second, 28 Law \& Contexr. Prob. 679, 684-86 (1963).

${ }^{16}$ Currie, The Disinterested Third State, 28 Law \& Corresur. Proв. 754, 757-64 (1963). 


\section{I \\ Estate of Perkins}

Wallace T. Perkins, a widower with a baby son, ${ }^{17}$ married Ella in Denver, Colorado in 1897. In 1904 the Perkms family moved to New York, where they hived until Wallace's death in $1931 .^{18}$ Perkins was a successful banker who amassed a great deal of money during the marriage. His wife apparently brought no property to the marriage and acquired none by her own efforts thereafter; ${ }^{19}$ but from time to time during the marriage she received gifts of securities from her husband. It was agreed ${ }^{20}$ that the only property Mrs. Perkins received from her husband was traceable either to his lifetime gifts or to the proceeds of $\$ 90,000$ dollars worth of insurance which Perkins maintained upon his life for the equal benefit of his wife, his son, and a friend. ${ }^{21}$

Shortly after her husband's death, Mrs. Perkins moved to Los Angeles to live near her three sisters. She brought with her some stocks and bonds and $\$ 19,000$ dollars in cash. In 1939, Mrs. Perkins died intestate in Los Angeles leaving an estate appraised at nearly $\$ 14,000$ dollars. She was survived by her three sisters and, it developed, by her husband's son, Clifford Perkins.

One of Mrs. Perkins' sisters, Lillian Middlebrook, was named administratrix of the estate. Early in 1940 she filed her final account praying for a distribution of the entire estate to herself and her two sisters as collateral kindred of the decedent under Probate Code section 225.22 Chiford Perkins objected, urging that distribution of the intestate's estate was controlled by Probate Code sections $228^{23}$ and $229,{ }^{24}$ and that under those

17 Opening Brief for Appellants, p. 1, in 6847 Records of the Supreme Court of California, p. 313 (1941).

18 Clifford Perkins, son of the decedent, apparently married and moved out of his father's house prior to his father's death. His residence at the time of his father's death and at the time of his step-mother's death is unknown.

19 Estate of Perkins, 21 Cal. 2d 561, 571, 134 P.2d 231, 237 (1943).

20 Ibid. Brief for Respondent, p. 2, in 6847 Records of the Supreme Court of California, p. 348 (1941).

21 Opening Brief for Appellant, p. 2, in 6847 Records of the Supreme Court of Cahfornia, p. 313 (1941).

22 Probate Code $\S 225$ provides: "If the decedent leaves neither issue nor spouse, the estate goes to his parents in equal shares, or if either is dead to the survivor, or if both are dead in equal shares to his brothers and sisters and to the descendants of deceased brothers and sisters by right of representation."

23 At the time of Mrs. Perkins' death, Probate Code $\$ 228$ provided: "If the decedent leaves neither spouse nor issue, and the estate, or any portion thereof was community property of the decedent and a previously deceased spouse ... such property goes in equal shares to the children of the deceased spouse and their descendants by right of representation."

24 At the time of Mrs. Perkins' death, Probate Code $\S 229$ provided: "If the decedent 
sections the entire estate came to him. The probate court rejected Clifford's claim and ordered the estate distributed in accordance with the administratrix's petition. Mrs. Middlebrook proceeded so to distribute the estate and was discharged, whereupon the stepson moved for and obtained a new trial. Following the retrial, the probate court reversed itself and ordered distribution of the bulk of the estate to Clifford pursuant to his interpretation of sections 228 and 229. Lillian Middlebrook appealed ${ }^{20}$ directly to the Supreme Court of California. Just as the probate court had done, the supreme court at first held unanimously that section 225 controlled and decided the case in favor of the sisters ${ }^{26}$ only to grant a rehearing ${ }^{27}$ and, by a four-to-three vote, ${ }^{28}$ reverse itself to decide the case in favor of the deceased lusband's son and the application of sections 228 and $229 . .^{20}$

Why, one may ask, did distribution of Mrs. Perkins' estate create such difficulties for two courts? There was no dispute about the facts: No one doubted that Mrs. Perkins was survived by three sisters who constituted her nearest surviving relatives, nor that the three ladies involved were those sisters. As for the stepson, he was not even in Mrs. Perkins' line of descent, as descent is commonly traced in this country and, indeed, in California. ${ }^{30}$ What, then, was the problem? The problem, of course, was and is that California has two systems of intestate succession: one for unmarried persons and another for widows and widowers. To be unore precise, Probate Code sections 288 and 229 apply to unmarried ${ }^{31}$ inte-

leaves neither spouse nor issue, and the estate or any portion thereof was separate property of a previously deceased spouse, and came to the decedent from such spouse by gift, descent, devise or bequest.... such property goes in equal shares to the children of the deceased spouse and to their descendants by right of representation."

25 The appeal was taken by "Lillian Middlebrook, administratrix of the estate." In the interests of justice, the court treated the title as descriptive to avoid the rule that an administratrix could not appeal from a decree of distribution. Estate of Perkins, 21 Cal. 2d 561, 566, 134 P.2d 231, 234 (1943).

28 Estate of Perkins, 120 P.2d 658 (Supreme Court of California 1941).

27 The rehearing was granted on January $29,1942$.

28 The composition of the court had changed since the first opinion. The first opinion was written by Justice Edmonds and signed by Chief Justice Gibson and Justices Shenk, Curtis, and Traynor. The second opinion was also written by Justice Edmonds. It was signed by Justices Shenk, Carter, and Schauer. Traynor's dissenting opinion was signed by the other two members of the prior majority, Chief Justice Gibson and Justice Curtis.

29 Estate of Perkins, 21 Cal. 2d 561, 134 P.2d 231 (1943). A petition for rehearing was denied March 11, 1943, by a 4-3 vote.

30 See generally, ATKINSON, WILLS \& 18 (2d ed. 1953).

31 If the decedent is survived by a second (or third, or fourth) spouse, the sections do not now apply although prior to the statutory amendments of 1939 the second spouse was excluded from inheriting property traceable to that acquired from the earlier one. Estate of McArthur, $210^{\circ}$ Cal. 439, 292 Pac. 469 (1930). See Ferrier, Rules of Descent Under Probate Code Sections 228 and 229, and Proposed Amendments, 25 CaLrF. L. REv. 261 (1937). 
state $^{32}$ decedents who were previously married but were not survived by issue, whose previous spouse has died, ${ }^{33}$ and whose estates contain community or separate property acquired from the previously deceased spouse. Section 225, on the other hand, applies to decedents who were never married and to previously married decedents whose estates contain property not acquired in this manner. ${ }^{34}$

Yet even this explanation will not serve to make plain the nub of dissent in Estate of Perkins. For it is perfectly clear that if Ella and Wallace Perkins lad married, lived, and died in Cahfornia, Clifford would have been entitled to the estate of his stepmother under sections 228 and 229.35 Indeed, because this result is so clear under California law, Professor Currie suggests that refusal to give the estate to Clifford under the facts of Perkins might deprive him of equal protection of the laws. ${ }^{36}$ The true focus of the controversy in the Perkins case, then, is that sections 228 and 229 expressly apply only to property in the decedent's estate which once was "community property of the decedent and a previously deceased spouse" or "separate property of a previously deceased spouse." The majority thought this meant the sections applied to "all property in which the predeceased spouse had some interest;" what it said: The sections applied to community and separate property. ${ }^{38}$ If the property had been acquired by a married couple domiciled in California, the two interpretations, while different in theory, produce identical results. This is so because under California law all property in which a "predeceased spouse had some imterest" would have been ultimately classifiable either as community or separate property. ${ }^{39}$ If, however, the

32 Estate of Wenks, 171 Cal. 607, 154 Pac. 24 (1915). See also Estate of Baird, 135 Cal. App. 2d 333, 287 P.2d 365 (1955).

33 The sections also may apply to property acquired by the decedent from a prior divorced spouse who had predeceased him. See I Arastrong, CaIIfornIa Fanuty LaW 770 (1953).

${ }^{34}$ E.g., Estate of Abdale, 28 Cal. 2d 587, 170 P.2d 918 (1946), discussed in text accompanying note 70 , infra.

35 Estate of Mercer, 205 Cal. 506, 271 Pac. 1067 (1928) (adopted daughter of predeceased spouse).

36 U.S. Const, amend XIV. See Currie, supra note 5, at 741; SeLected Essays at 651. $3721 \mathrm{Cal} .2 \mathrm{~d}$ at $569,134 \mathrm{P} .2 \mathrm{~d}$ at 236.

38 Id. at 572,134 P.2d at 238.

$39 \mathrm{~A}$ husband and wife in California may hold property as joint tenants, tenants in common, or as community property. CAL. CIv. CoDE $\S 161$. If the property is held as community property it cannot also be held as joint tenancy because the distinguishing incidents of joint tenancy are inconsistent with the community estate. Tomaier v. Tomaier; 23 Cal. 2d 754, 758, 146 P.2d 905, 907 (1944). In the absence of any evidence of an intention to the contrary, property held in joint tenancy will be held by the spouses as separate property. Delanoy v. Delanoy, 216 Cal. 23, 26, 13 P.2d 513, 514 (1932). There is no inconsistency between cominunity property and tenancy in common and property held by the spouses as tenants in common may be either community or separate. Dunn v. Mullan, 211 Cal. 583, 296 Pac. 604 (1931). 
property was acquired by a married couple domiciled in a state (such as New York) which does not provide by law for the marital community of acquets and gains, or, if it was acquired by a married couple domiciled in another community property state (such as Texas) which has a different method of classification ${ }^{40}$ than California, then of course, the competing interpretations would lead to different results. Traynor would not apply sections 228 and 229 if the property would not have been classified as community or separate property either at the time it was acquired or at the time it was brought to California, ${ }^{41}$ while the majority would apply the sections "to all property subject to probate proceedings in California," thus applying the community-separate property classifications for the first time upon the decedent's death. ${ }^{43}$

Estate of Perkins was not a case of first impression. Not only had it been preceded by a long series of cases dealing with the general question of Cahifornia's power to apply her community property laws to married persons who moved to Cahifornia bringing with them property acquired in common law states, ${ }^{44}$ but Estate of Allshouse ${ }^{45}$ had raised and decided the precise issue of the Perkins case in favor of a more limited reading of sections 228 and 229. A law review note ${ }^{46}$ on Allshouse would have preferred the interpretation that Traynor later proposed, but in general the

$40 \mathrm{In}$ Texas, the rents and profits of separate property belong to the commumity. Arnold v. Leonard, 114 Tex. 535, 273 S.W. 799 (1925).

41 Estate of Perkins, 21 Cal. 2d 561, 573, 134 P.2d 231, 238-239 (1943).

42 Id. at 570, 134 P.2d at 236.

43 Ibid. Currie states that "no 'reclassification' in accordance with community property concepts seems necessary," but the majority was required to reconcile its interpretation with the wording of the statute. The words "commumity" and "separate" property are, to say the least, words of art in California law. Currie, supra note 5, at 740, SELECrED EsSAYs at 650 .

44 See generally Schreter (now Kay) "Quasi-Community Property" in the Conflict of Lawes, 50 CALIF. L. REv. 206 (1962).

4513 Cal. 2d 691, 91 P.2d 887 (1939). The couple lived in Missouri and the husband died there. After his death, the wife moved to California. She died, intestate, in California leaving as survivors three brothers, a sister, and a nephew. Her husband's son by a prior marriage claimed her estate under sections 228 and 229. The court arrived at a result that falls between the majority and minority views in Perkins: it decided to "trace the origin of an estate into a foreign jurisdiction and to there apply a California classification, provided the foreign ownership possessed substantially the incidents of the California property holding which it is to be classified." Id. at 697-98, 91 P.2d at 890 . Using this test, the court reclassified property owned hy the liusband prior to his marriage or acquired afterward by gift, devise, descent or bequest as separate property; it refused to reclassify his earnings as cither community or separate property; and it reclassified one half of a parcel of California realty held in joint tenancy with his wife as separate property of the husband that had gone to the wife by inter vivos gift. For a criticism of this approach, see Professor Ferrier's note on the Perkins case, Note, 31 CALIF. L. REv. 331, 332 n.4 (1943).

46 Note, 28 CaLfF. L. REv. 96 (1939). 
writer was favorable. The first Perkins opinion ${ }^{47}$ followed Allshouse without question, and its overruling in the second Perkins opinion ${ }^{48}$ seems to have come as an unwelcome surprise. ${ }^{49}$

How is the majority's interpretation of sections 228 and 229 to be defended? The opinion itself contains no persuasive reasoming in support of the result. As Justice Traynor accurately pointed out, the majority merely "construed the legislative purpose to extend beyond the legislative language and then read into the language an implication that alone would make possible the execution of the enlarged purpose. ${ }^{250}$ Professor Currie, providing the court's missing analysis, relies on Professor Ferrier's thouglitful historical article ${ }^{51}$ to suggest that the sections embody the common-law doctrine of ancestral property ${ }^{52}$ and argues that the policy of that doctrine applies indistinguishably to common law and community property states alike. ${ }^{53}$ To test his view, Currie offers a hypothetical case: A Cahifornia husband and wife agree that their future earnings shall be the separate property of each instead of the community property of both. Correctly assuming that such an agreement is permissible under California law, ${ }^{\text {,4 }}$ Currie argues that property earned after the agreenent became effective is not, strictly speaking, "separate property," and then concludes that the husband's accumulated earnings acquired under such an agree-

47 Estate of Perkins; 120 P.2d 658 (Supreme Court of California, 1941).

48 Estate of Perkins, 21 Cal. 2d 561, 570-71, 134 P.2d 231, 237 (1943).

40 Ferrier, supra note 45.

v0 Estate of Perkins, 21 Cal. 2d 561, 572, 134 P.2d 231, 238 (1943).

51 Ferrier, Rules of Descent Under Probate Code Sections 228 and 229, and Proposed Amendments, 25 Carre. L. REv. 261 (1937). It should perhaps be noted that Professor Ferrier's note on the Perkins case agreed with Traynor's position. Note, 31 CALIF. L. REv. 331, 334 (1943).

52 Currie, Justice Traynor and the Confict of Lawes, 13 STAN. L. REv. 719, 736 (1961), Selected Essays at $629,646$.

53 Ibid. In this connection, it is interesting to note that the California Supreme Court, in rejecting an argument seeking to hmit the precursor of section 228 to the identical property possessed by the predeceased spouse, and applying instead the familiar tracing doctrine of California community property law, refused to follow cases from other jurisdictions which had himited similar statutes to the identical property acquired from the predeceased spouse. The court thus distinguished those cases: "[N]one involved the precise question we have here, in view of our community and separate property system and the well-settled rules in regard thereto. It is in the light of the well-understood policy in this matter that our statute is to be construed. ..." Estate of Brady, 171 Cal. 1, 7, 151 Pac. 275, 277 (1915). The Ohio provision, similar to CAL. PROB. CODE $\$ \S 228$ and 229 is expressly limited to "identical real estate or personal property which came to such relict from any deceased spouse" OHIo REv. CODE ANv. \$ 2105.10 (Page, 1954). See generally White, Ohio's "Half and Half" Inheritance Statute, 15 U. Cinc. L. Rev. 401 (1941); Pierson, The Ancestral Status of Personal Property, 16 Geo. L.J. 341 (1927-28); Annot. 49 A.L.R.2d 391 (1956).

54 CaI. Crv. Code $\$ 158$; Kaltschmidt v. Weber, 145 Cal. 596, 599-600, 79 Pac. 272, 27374 (1904); Wren v. Wren, 100 Cal. 276, 279-81, 34 Pac. 775, 776 (1893); I Ararstrong, California Fanarly Law 541-65 (1953). 
ment and bequeathed to his wife by will would subsequently constitute section 229 separate property in her imtestate estate. ${ }^{65}$ He then compares the result in his hypothetical case with the facts of Perkins, and concludes that there is no substantial difference between Mr. Perkins' common law earnings and the earnings of a liypothetical California husband who has obtained his wife's consent to hold his future earmings as his separate property. ${ }^{58}$

In my view, the force of Currie's argument is weakened by the mistakes he makes about California community property law. ${ }^{57}$ Thus, it seems clear that community property earnings which are the subject of an interspousal agreement such as Currie postulates become "separate property" in the strictest sense of that term. Currie objects that such property was not "acquired before marriage or acquired thereafter by gift, bequest, devise, or descent" and thus is not separate property. ${ }^{68}$ The California Civil Code, however, contains other provisions besides sections 162 and 163 that define separate property. Thus, the earnimgs of a wife living separate and apart froin her husband are her separate property; ${ }^{60}$ the earnings of a husband following the entry of an interlocutory decree of divorce are his separate property; $;^{60}$ and the earnings of both husband and wife become separate property following a decree of separate maintenance. ${ }^{61}$ Under a rather confusing statute, ${ }^{62}$ the earnings of a husband whose wife unjustifiably abandons hin are his separate property until she offers to return. Since 1957, damages awarded to a married person in a civil action for personal injuries have been separate property. ${ }^{83}$ The Legislature has not been alone in supplementing sections 162 and 163. Thus, it has been judicially established that in the absence of any evidence of a contrary intent, when a husband and wife use community funds to purchase real property, taking title as joint tenants, the community property is deened severed by consent and the interest of each spouse becomes his separate property. ${ }^{64}$ Similarly, the earnings of a wife which are subject to

55 Currie, supra note 52, at 737-39, Sexected Essays at 648-50.

60 Id. at 739-40, Serected Essays at 650-51.

57 With his customary foresight, Currie has protected himself in advance against precisely this criticism: Before setting sail for the never-never land of community property law, he disclaimed all expertise by saying that "a common-law lawyer must approach with diffidence, if not trepidation, anything that smacks of commumity property." Currie, supra note 52, at 733, Secected EsSAYs at 643.

58 Currie, supra note 52, at 738, Selected Essays at 648 . The definition is drawn from Cax. Crv. CoDE $\S \S 162,163$, which in turn are based on Cax. Const. art. XX, \& 8 .

59 Cax. CTv. Code $\$ 169$.

80 CAL. Crv. Code \& 169.2.

61 Cax. Crv. CODE \& 169.1.

62 Cat. CTv. Code $\& 175$.

63 CAL. CTV. CODE \& 163.5.

64 Delanoy v. Delanoy, 216 Cal. 23, 13 P.2d 513 (1932); Tomaier v. Tomaier, 23 Cal. 
an agreement like the one Currie postulates become her separate property. ${ }^{65}$ I see no reason for saying that separate property created by agreement of the spouses is any less "separate" than any of the other non-162 and 163 types of separate property..$^{66}$

Apart from whether community property earmings which the spouses have agreed to lold as separate property are "true" separate property or not, it is clear that the question of characterizing such property during the joint life of the spouses must be sharply distinguished from its characterization for the purposes of applying sections 228 and 229 after both spouses have died. The cases have established that in applying sections 228 and 229 the original source of the property is controlling, not its

2d 754, 146 P.2d 905 (1944). The text statement expresses the meaning of the quotation from Siberell v. Siberell, 214 Cal. 767, 771, 7 P.2d 1003, 1004 (1932) relied on by Currie to the effect that "in California we have a modified form of certain estates known to the common law and have them operating alongside of the community property system ...." Currie, supra note 52, at 738 , Selected Essays at 648. The problem in Siberell was to what extent community rights and joint tenancy rights can co-exist in the same item of property. The court said that the two types of ownership were inconsistent and that the use of community funds to acquire real property in joint tenancy form must be deemed "a binding agreement" to hold the property as separate property. Even so, the separate property ownership of joint tenancy property must be viewed exactly as any other separate property in a community system. See note 39 supra. It has recently been argued that Siberell was wrong and that commumity property can be held in joint tenancy. See Griffith, Communtity Property in Joint Tenancy Form, 14 STAN. L. REv. 87 (1961). In any event, Siberell was quickly limited by Delanoy so that the "binding agreement" became a mere inference. Chief Justice Traynor later cut Siberell down even more critically by pointing out that "[I]n its holding, as distinguished from its language, the Siberell case established only that whether such property is a joint estate or community property, the trial court in a divorce proceeding has the power to divide the property equally." Tomaier, supra at 759, 146 P.2d 907.

05 E.g., Kaltschmidt v. Weber, 145 Cal. 596, 79 Pac. 272 (1904); Wren v. Wren, 100 Cal. 276, 34 Pac. 775 (1893); Larson v. Larson, 15 Cal. App. 531, 115 Pac. 340 (1911). See Evans, Primary Sources of Acquisition of Community Property, 10 CAIIF. L. REv. 271, 274 (1922).

68 Currie again relies on an unfortunate generalization from Siberell v. Siberell, $214 \mathrm{Cal}$. $767,770,7$ P.2d 1003, 1004 (1932) for the argument that property which is not community is separate "for want of a better name." Currie, supra note 52, at 738, Sexected Essays at 648. All the presumptions of the community property in California are exactly contrary to the statement in Siberell. Thus, Civil Code $\$ \S 162$ and 163 define, generally, separate property; $\delta 164$ then provides that "all other ... property . . . is community . . . ." Even $\S 687$, rehied on in Siberell for the statement quoted by Currie, reinforces the opposite view: it provides that "commumity property is property acquired by husband and wife, or either, during the marriage, when not acquired as the separate property of either." (Emphasis added.) Far from meaning, as Siberell suggests, that "all property not held as community property must, for want of a better name, be classed as separate property," the section means that all property not held as separate property innst be classed as community. The point is not merely a quibble: in Estate of Jolly, 196 Cal. 547, 238 Pac. 353 (1925), for example, the estate passed as community property because no one could prove it was separate property. The presumption favoring the community is one of the inost firmly-embedded principles of the California system. See I Armstroíg, Califorama Fammy LAw 440-75 (1953). 
character at death. ${ }^{67}$ Thus, in Estate of Reizian, ${ }^{68}$ residential property was acquired in the wife's name after the marriage. The purchase money for the property was held to be savings acquired by the wife before marriage. It was argued that she had converted the residence into community property by inaking a joint and mutual will with her husband stating that all of the property possessed by either was community. The court held that, even if the agreement contained in the wills converted the property to community property upon the death of the husband, for the purpose of applying 228 and 229 upon the subsequent death of the wife "those wills . . . did not change, and could not change, the source of consideration for its purchase which is the controlling factor in this proceeding." $" 69$

As it happens, this point is also established by one of Chief Justice Traynor's opinions. In Estate of Abdale, ${ }^{70}$ the husband owned several parcels of real property before his marriage. After his marriage, he placed the property in joint tenancy with his wife, thus making a gift to her of an undivided one-half interest in the property as her separate estate. Upon his wife's death in 1941, the husband reacquired the property by survivorship. When he died intestate in 1943 his estate consisted almost entirely of funds traceable to the sale of this property. The contestants were the legal representatives of the predeceased wife's incompetent son by a prior marriage and representatives of the husband's deceased brothers. The representatives of the stepson claimed that one-half of the property had been the wife's separate property which had vested in the husband by right of survivorship in a joint tenancy and therefore passed under section 229. The representatives of the husband's brothers argued, on the other hand, that since the original source of the joint tenancy property had been the husband's separate property acquired prior to his marriage, the

67 Estate of Allie, 50 Cal. 2d 794; 329 P.2d 903 (1958); Estate of Reizian, 36 Cal. 2d 746, 227 P.2d 249 (1951); Estate of Abdale, 28 Cal. 2d 587, 170 P.2d 918 (1946); Estate of Rattray, 13 Cal. 2d 702, 91 P.2d 1042 (1939).

6836 Cal. 2d 746, 227 P.2d 249 (1951).

69 1d, at 751, 227 P.2d at 251. Currie cites Estate of Watkins, 16 Cal. 2d 793, 108 P.2d 417 (1940), as "suggestive" of the proposition that if a husband and wife convert community property into joint tenancy the resulting interests are "an analogue of common-law property" which might indicate that the husband's earnings in his bypothetical case would pass as 229 property in the surviving wife's estate. Currie, supre note 52, at 739, SELECTED Essays at 649-50. In Watkins, the husband and wife converted community property into joint tenancy and then back to cominunity property by mutual wills. The court appears to bave relied solely upon the agreement in the wills to reconvert the property to commumity status for purposes of $\$ 228$. Reizion, however, must be taken as having established that such reliance is unnecessary because the original source of the property was commumity. Even if the wills be ignored as Currie suggests, then, the "joint-tenancy" property in Watkins would pass under $\S 228$ because it was traceable to a community source.

7028 Cal. 2d 587, 170 P.2d 918 (1946). 
property could not be viewed as having been acquired from the wife. Relying on the leading case of Estate of Rattray ${ }^{71}$ and citing many supporting cases, ${ }^{72}$ Traynor held that the origin or source of the property controlled its disposition. In the circumstances of $A b d a l e$, this general principle meant that the property must be distributed to the husband's brothers under Probate Code section 225, because its original source was the decedent's separate property, although its intermediate source was a joint tenancy that vested in the decedent on the death of his predeceased spouse.

What is the "source" of a husband's earnings acquired under an interspousal agreement such as the one described by Currie? It is clear from this brief review of the cases that earnings acquired prior to the agreement originated as community property and that such accumulated earnings would pass under section $228 \mathrm{~m}$ the surviving wife's estate. Although no case has squarely passed upon the point, it seems clear that Currie accurately concludes that section 229 would apply to accumulations of earnings acquired after the agreement. Thus, the "source" test refers to the status assigned to property at the time of its acquisition. Since the husband's earnings were originally acquired under the agreement, he possessed them initially as separate property. Similarly, a wife's cause of action for personal injuries, which would have been community property but for a prior agreement with her husband that all her property would be held as separate property, originated under the agreement as her separate property, thus making an otherwise improper assignment by the husband unnecessary. ${ }^{73}$

Since one of the accepted purposes of 228 and 229 is to divide marital earnings equally between the families of both spouses, ${ }^{74}$ classifying a husband's earnings as separate property under section 229 is inconsistent with the statutory policy no matter whether the husband acquired the property in California ${ }^{75}$ or New York. ${ }^{76}$ That one inconsistency is required

7113 Cal. 2d 702, 91 P.2d 1042 (1939).

7228 Cal. 2d at 590,170 P.2d 918 at 921.

${ }^{78}$ See Perkins v. Sunset Tel. \& Tel. Co., 155 Cal. 712, 103 Pac. 190 (1909). Although the court in this case failed to distinguish between the prior agreement and a subsequent relinquishment by the husband given after the cause of action had arisen, Traynor made clear in Kesler v. Pabst, 43 Cal. 2d 254, 273 P.2d 257 (1954) that a subsequent relinquishment would involve the husband's exercise of control over the cause of action and hence would not be effective to prevent him from profiting from his own wrong. Insofar as Perkins $v$. Sunset Tel. \& Tel. Co. avoided being overruled on this point by Kesler, then, its continued authority must be placed solely on the prior interspousal agreement. The enactment of CAx. CIv. CODE $\& 163.5$ in 1957 now makes causes of action for personal injuries separate property in any event.

74 E.g., Estate of Rattray, 13 Cal. 2d 702, 713, 91 P.2d 1042, 1048 (1939).

75 Currie, supra note 52 at 740 , Selected Essays at 651.

76 Estate of Perkins, 21 Cal. 2d 561, 577-78, 134 P.2d 231, 237-38 (1943). 
to maintain the freedom of California husbands and wives to change the nature of their property by agreement, however, does not justify another inconsistency in the case of common law earnings. If the nature of the California husband's earnings, even when held as separate property, is different from the New York husband's common law earnings, distribution of the California earnings under 229 does not compel the same distribution of the New York earnings. Currie does not contend that California separate property is the same thing as common law property; instead, he mistakenly concludes that separate property created by interspousal agreement is not the same as separate property created by Civil Code sections 162 and 163. Since his hypothetical case was based on that conclusion, I assume he would now agree that the husband's earnings in his case are true separate property; that they are different from common law property; ${ }^{77}$ and that he would accordingly no longer object to Traynor's conclusion in Perkins as a matter of community property law.

After going around the mulberry bush of community property law, we have finally arrived at Perkins as a conflict of laws case. I am a little embarrassed, after having taken so long to get here, to confess that I do not think Perkins is a conflicts case at all. At least, the problem that the majority opinion sets up for itself is not a conflicts problem. Traynor's dissent, on the other hand, is a conflicts opmion; and therein hes the point of his objection to the majority's interpretation of Probate Code sections 228 and 229. Traynor reads those sections as requiring a reference to foreign law to establish the datum point of whether the decedent's property was originally acquired by the spouses during their lifetime as community or separate property. If the answer to that question is "no" for the reason that the state in which the spouses were domiciled at the time the property was acquired was not a community property state, then sections 228 and 229 do not apply. ${ }^{78}$ If the answer is "yes," whether because the

77 I have discussed some aspects of the differences in a prior article. Schreter (now Kay) "Quasi-Community Property" in the Conflict of Laws, 50 CarrF. L. REv. 206, 206-209 (1962). See generally Marsh, Maritac Property iv Conflict of Laws 27-67 (1952).

78 Perkins was decided after Estate of Thornton, 1 Cal. 2d 1, 33 P.2d 1 (1934) had held unconstitutional the legislature's general attempt to alter marital interests in property acquired elsewhere by spouses who moved to California and prior to the enactment of the more limited quasi-community property statutes of 1961. (CAL. Crv. CodE $\$ 140.5$ et seq.) Those sections, however, are operative upon divorce or separate maintenance and do not affect Traynor's reasoning in Perkins. Probate Code $\$ \S 228$ and 229 have not been amended to apply to quasi-comniunity property acquired upon divorce from a spouse who predeceased the decedent; nor is there any good reason why such property should be included within those sections, particularly when it is not clear that comnunity or separate property acquired from a predeceased divorced spouse is included. See note 33 supra. Although my argument supporting the legislature's constitutional power to reclassify the property of married persons who become domiciled in California upon arrival (Schreter (now Kay) stcpra note 77 ) leads ne to agree that the legislature could properly apply 228 and 229 to property 
case is entirely domestic or because the foreign state is a community property jurisdiction, then 228 and 229 will apply. ${ }^{79}$ The application of the sections, then, is made to depend on the foreign law. In the majority's view, however, the foreign law is totally irrelevant: The sections will be applied to all cases in which a California decedent's estate contains property acquired fronı a predeceased spouse. To be sure, Traynor's opinion is not concerned with a reference to foreign law to find a rule of decision; in his view, the foreign law merely supplies a datum made relevant by Cahifornia law.$^{80}$ But the difference in approach taken by the two opinions provides an important insight into the general problem of why courts refer to foreign law.

Currie has not yet dealt fully with the question of distinguisling between the different purposes for which a court refers to foreign law. $\mathrm{He}$ has, however, suggested that a broad distinction exists between "(1) [T] he purpose of finding a rule of decision and (2) all other purposes, including that of finding some datum made relevant by the rule of decision supplied by the law of the forum." 81 Currie has insisted that his governmental interests approach to conflict of laws is limited, at least for the time being, to cases where the purpose of the reference to foreign law is to find the rule of decision. ${ }^{82}$ Michael Traynor has suggested that the careful analysis of the forum's policy and interest required by Currie's approach is helpful even when the foreign law is not referred to for a rule of decision. ${ }^{83}$ I agree with his suggestion and I think Estate of Perkins illustrates that difficult problems of local policy can be hidden behind the "datum" label unless the distinction is applied by a judge knowledgeable in conflicts methodology. The elaboration of this point will be aided, however, by a brief side glance at Currie's earher discussions of the general area.

acquired in common law states when both spouses became domiciled in California in cases like Estate of Krey, 183 Cal. App. 2d 312, 6 Cal. Rptr. 804 (1960) and Estate of Ball, 92 Cal. App. 2d 93, 206 P.2d 1111 (1949), the same considerations do not apply to cases like Perkins and Estate of Allshouse, 13 Cal. 2d 691, 91 P.2d 887 (1939) where the predeceased spouse was never a Californian. California's desire to equalize the property relations of all married couples domiciled here does not extend to unmarried persons.

79 If the property was acquired in another community property state, I assume Traynor would make the classification under the law of that state in cases where the California classification would be different. Thus, if the property was acquired in Texas and the husband had died there, the rents, issues, and profits of his separate property would be considered community property in the wife's estate. See note 40 supra.

80 The terminology is, of course, Currie's. See text at note 81 , infra.

81 Currie, The Disinterested Third State, 28 Law \& Contemp. Pros. 754, 756 (1963).

82 Currie, Notes on Methods and Objectives in the Confict of Laws, 1959 DURE L.J. 171, 173, SeIECTed Essays at 177-78; Currie, The Disinterested Third State, 28 Law \& ConTEMP. Prob. 754, 756 (1963).

${ }^{83}$ M. Traynor, Conflict of Laws: Professor Currie's Restrained and Enlightened Forum, 49 CAIIF. L. REv. 845, 873-75 (1961). Professor Ehrenzweig has suggested that "the ghost 
When does the datum-rule-of-decision dichotomy become important to a court deciding a conflict of laws case? The answer to that question depends, I think, on how broadly the forum interprets its own law. In some cases, such as those involving whether one drives to the left or right of the center of the road, it is clear from a construction of the forum's rule of the road "in the light of the policy which that law embodies and the interest of the forum state in effectuating that pohcy"84 that it does not apply outside the forum's state boundaries. In other cases, however, the result of a similar process of interpretation may be that the forum's law does apply to acts that occurred elsewhere. The choice between these two positions should be a conscious one, made with the lielp of Currie's method, even if the foreign law is called upon only to supply a datum point rather than a rule of decision. Thus, in Currie's workmen's compensation illustration, ${ }^{85}$ the question for decision is whether a woman who had been living with a deceased employee as his wife is a "widow" within New York compensation law if their marriage was invalid under the law of Italy, the place of celebration. As Currie points out, the case may be handled in several ways: the New York court may decide that the entire question turns on whether the couple were validly married under the law of Italy; it may decide that the question turns on whether they would have been validly married under New York law, no matter what the law of Italy provides; or it may decide that the vahility of the marriage, and therefore the Itahian law, is entirely irrelevant and that the question will be settled by an examination of whether New York's social and economic policy extends to providing a death benefit for women who were factually dependent upon deceased New York employees. The foreign law supplies a "datum" only in the first of these alternative methods; in the other two, New York's expanded interpretation of her own law has made reference to foreign law unnecessary.

The point may become clearer by using Michael Traynor's illustration: ${ }^{86}$ the California decision in Estate of Lund. ${ }^{87}$ In that case, the question was whether the illegitimate son of a California decedent could share in the father's estate. Under California law, the son could inherit only if he had been legitimated by his father during his lifetime. ${ }^{88}$ No provision of

of the 'prehminary question' . . . is not far away." Ehrenzweig, Choice of Law: Current Doctrine and "True Rules", 49 CALIF. L. Rev. 240, n.6 (1961).

84 Currie, On the Displacement of the Law of the Forum, 58 ColuM. L. REv. 964, 1014 (1958), Selected Essays at 60. See Walton v. Arabian Am. Oil Co., 233 F.2d 541 (2d Cir. 1956).

85 Currie, supra note 84, at 1022-24; SexECTEd Essays at 70-71.

$86 \mathrm{M}$. Traynor, supra note 83 , at $874-75$.

8726 Cal. 2d 472, 159 P.2d 643 (1945).

88 Under Cahfornia law, inheritance from the father of an illegitimate child depends either on legitimation or on acknowledgment in a written instrument. The latter method was 
foreign law operated to legitimate the son in any state in which the father, his family, and the son had lived together. California, however, has a statute which permits the father of an illegitimate child to legitimate him by performing certain acts: publicly acknowledging the child as his own, receiving him into his family with the consent of his wife if he is married and otherwise treating him as though he were legitimate. ${ }^{89}$ These acts had been performed by the father in Minnesota and New Mexico, but not in California. If the problem of whether legitimation has occurred is treated as a "datum point" and viewed as a question of status ${ }^{90}$ to be decided under foreign law, the answer will be that no legitimation has occurred. But if the problem is whether the status of legitimation has been achieved under California law, the son nuay be permitted to inherit by extending the California statute to acts performed elsewhere by a local decedent. The first question poses a problem in the conflict of laws; the second does not.

In both the workmen's compensation case and Estate of Lund, whether or not the foreign law will be permitted to decide the collateral issue by furnishing a datum point depends on how far the forum wishes to extend the policy of its own law. In Sutton v. Lieb, ${ }^{91}$ lowever, the foreign law plays a quite different role. In that case, an Illinois alimony decree expressly terminated on the wife's renrarriage. The wife, Verna, niarried Walter Henzel following his Nevada divorce. Henzel's first wife subsequently obtained a New York separate maintenance judgment declaring his divorce, and consequently the remarriage, invalid. Verna procured an aunulment of her marriage to Henzel in New York and thereafter sued in Illinois to enforce the alimony decree against her first husband. The Supreme Court held as a matter of federal law that the full faith and credit clause coinpels Illinois to recognize the New York judgment as terninating the remarriage but that the interpretation of the Illinois alimony decree was a matter of state law unaffected by its holding. ${ }^{92}$ Unlike the effect of a reference to foreign law in Lund and the workmen's compensation case, a reference to New York law in Sutton v. Lieb simply is not relevant to a decision of whether a void reniarriage is a "remarriage" for the purpose of an Illinois alimony decree. The New York judgment merely poses the question; it can be decided only by Illinois law. Indeed, the identical question has arisen in a purely domestic case. In Sefton $v$. Sefton, ${ }^{93}$ a

not available on the facts of the Lund case. See CAL. ProB. CODE \& 256; Blythe v. Ayres, 96 Cal. 532, 31 Pac. 915 (1892).

89 CaI. Civ. COde $\$ 230$.

90 See Eerenzweig, Conflicts IN A NUtsherd \& 3 (1965). (Discussing the relationship between status and datum.)

91342 U.S. 402 (1952). See Currie, supra note 84, at 1024; Serected EsSays at 72.

92342 U.S. 402, 408-9; Currie, supra note 84, at 1024; SeIected Essays at 72.

8345 Cal. 2d 872; 291 P.2d 439 (1955). 
.California wife's alimony agreement expressly provided for termination on her remarriage. She remarried in California and within a week her second inarriage was annuled in California. The California annulment, like the New York judgment in Sutton v. Lieb, simply made the interpretation of the word "remarriage" necessary; neither could help to decide the question.

Situations exist, however, where the forwn law itself requires the application of foreign law to settle a collateral issue by supplying a datun point. The reciprocal inheritance statutes ${ }^{94}$ provide a convenient illustration. In these cases the legislature las already determined the extent of the forum's policy: A non-resident alien will be permitted to inherit California land only if the law of his domicile permits an American the same privilege. The rule of decision will be supplied by Cahifornia law; but the statute lias placed upon the foreign law the burden of providing the datum point upon which application of the forun's law depends.

Similarly, a court may judicially declare the himits of the forum's policy; and by so doing may decide that the content of a foreign law will provide the basis for applying or withholding a given provision of local law. In Traynor's view, Estate of Perkins was such a case. For him, the question was not whether the California legislature had the power to extend the policy of sections 228 and 229 to property acquired in common law states; nistead, the question was "whether the legislature has exercised its power in this particular legislation." mittedly chosen to extend the policy of the community property system to spouses who moved to California from common law states; its statutory scheme of reclassification had been declared unconstitutional. ${ }^{20}$ In the case of sections 228 and 229 the legislature had chosen to accord special significance of the previous marital status of property in the decedent's estate only if the property las been, during his lifetime, "community" or "separate" property. The court should read those words as words of limitation; they "relate to classifications that existed during the lives of the spouses." In a case where the property was acquired elsewhere, the sections required that the classification be made under the foreign law: Here, since New York was the only state that had any conceivable interest in the spouses at the time the property was acquired, New York law controls the application of the California policy. As in the reciprocal inheritance statute, a reference to foreign law is used to set the limits of local policy.

94 Currie, supra note 84, at 1019-20, Serected Essays at 67. See CaL. Prob. Code $§ 259$. 95 Estate of Perkins, 21 Cal. 2d 561, 572, 134 P.2d 231, 237 (1943).

${ }^{96}$ Estate of Thornton, 1 Cal. 2d 1, 33 P.2d 1 (1934). See Schreter (now Kay), supra note 77. And see note 78, supra.

9721 Cal. $2 \mathrm{~d}$ at 573,134 P.2d at 238. 
One of the major differences between cases involving a reference to foreign law for the purpose of establishing a datum point and for the purpose of finding a rule of decision is that in the datum point cases, typically, there is no potential conflict of policy and interest with another state. Of course, as Currie has established beyond question, many potential conflicts cases turn out to be merely "false" conflicts: either the foreign state has no interest in the assertion of its policy or the interests of the forum may be defined moderately to avoid a conflict. As he has justly said: "The clearest contribution of governmental-interest analysis to conflict-of-laws method is that it establishes the existence of such false problems and provides a workable means of identifying them."198 But in the datum point cases, there is usually not even a potential conflict of interests. Can anyone imagine that Italy would assert an interest in liaving the woman in the New York workmen's compensation case demed a death benefit or that the interests of Minnesota or New Mexico would be offended by California's permitting Bert Lund to share in lis father's estate? And, far from creating a conflict of interests, the reciprocal inheritance statutes are drafted precisely for the purpose of creating a community of interest between the forum and the foreign country to the end that commensurate rights will be created in each for the citizens of the other.

That no opposing policy and interest of a foreign state or nation will be asserted to check the sweep of the forum's policy does not mean, however, that the forum should extend its law to cover all possible situations.99 Indeed, such have been the blandishments of the traditional system of conficts analysis that the forum may not realize that no true conflict of interests is involved. Both the majority and dissenting opinions in Estate of Lund expended great energy worrying about the "extraterritorial application" of the California legitimation statute. The majority even felt constrained to construct a new theory, the doctrine of "factual significance," to account for the application of California law to acts of a California decedent performed in other states: Mr. Lund, by receiving his son into his family and fulfilling the other acts required for a Cahfornia legitimation in Minnesota and New Mexico, had thereby conferred upon his son in those states the "de facto status of a inember of [his] family;" that status continued to exist until Mr. Iund became domiciled in a state whose laws attached a legal significance to the factual status and so performed the legitimation. Recognition of the absence of a true conflict of policy

98 Currie, The Disinterested Third State, 28 Law \& Contemp. Prob. 754, 756 (1963).

89 See Baade, Foreword, 28 LAw \& Contearp. Prob. 673, 674-77 (1963). I have assumed throughout this discussion that the forum's analysis of its own policy and interests correctly indicates that no constitutional obstacle exists to the application of forum law. See generally Currie, The Consitution and the Choice of Law: Governmental Interests and the Judicial Function, 26 U. Chr. L. Rev. 9 (1958), SeIected EsSAYs 188. 
and interest with Minnesota and New Mexico would have inade most of this elaborate reasoning unnecessary. It would not, however, have rendered pointless a sensitive interpretation of California's policy and interests to determine whether, as a matter of local law, the statute should be extended to cover this case. California might decide, as one judge suggested of a statute providing for legitimation by marriage, ${ }^{100}$ that the provision is "manna for the bastards of the world,"101 but it might also decide that the policy of its statute is not so extensive as to apply even to acts performed by a local decedent in neighboring states. In either case, however, the matter is one for California law. Similarly, in Estate of Perkins the initial question was one of local law. Accordingly, Traynor's opinion first deals with the policy of sections 228 and 229 and then decides that those sections permit the relevant foreign law to establish the himits of their application. In Traynor's hands, Estate of Perkins would have been both a perceptive analysis of domestic policy and an imaginative use of conflict of laws method.

\section{II}

\section{Bernkrant v. Fowler}

Bernkrant v. Fozeler ${ }^{102}$ was an action against a decedent's estate to cancel a promissory note. The plaintiffs were businessmen who had refinanced their obligation to the decedent at his request in exchange for his promise to forgive any remaining indebtedness in his will. Since the promise was oral and since the anticipated provision did not appear in the will, the case raises a problem of the statute of frauds. Further, since the plaintiffs were residents of Nevada, where the relevant statute of frauds did not apply to invalidate the contract, and the decedent died domiciled in California, where the statute of frauds if applicable would invalidate the contract, the case also raises a problem in the conflict of laws.

Enough has been written ${ }^{103}$ about the statute of frauds and the conflict of laws by now to lead even the most optimistic of readers to despair of finding many sensible judicial opinions upon the topic. Even the few exceptions ${ }^{104}$ to this dismal outlook merely serve to darken the surrounding

100 CaL. Crv. COde \$ 215.

101 Blythe v. Ayres, 96 Cal. 532, 563, 31 Pac. 915, 917 (1892).

10255 Cal. 2d 588, 360 P.2d 906, 12 Cal. Rptr. 266 (1961).

103 E.g., Ehrenzweig, The Statute of Frauds in the Conflict of Laws: The Basic Rule of Validation, 59 Colos. I. REv. 874 (1959); Lorenzen, The Statute of Frauds and the Confict of Laws, 32 YaIE L.J. 311 (1923): HeIrMan, ThIE Conflict of Laws and the StatuTe of Fradds (1961); Currie \& Schreter (now Kay), Unconstitutional Discrimination in the Confitit of Laws: Privileges and Immunities, 69 YALE L.J. 1323, 1326-35 (1960).

104 Rubin v. Irving Trust Co., 305 N.Y. 288, 113 N.E.2d 424 (1953); Lams v. F. H. Smith Co., 36 Del. 477, 178 Atl. 651 (1935); Emery v. Burbank, 163 Mass. 326, 39 N.E. 1026 (1895). See Cavers, Oral Contracts to Provide by Will and the Choice of Law Process: 
gloom by contrast. Whenever a conflicts opinion begins with the words "Traynor, J.," however, the chances are overwhelming that another area of conflicts law is about to be illuminated. Bernkrant v. Fowler more than fulfilled its promise: it was positively electrifying. As Currie delightedly pointed out, Bernkrant was probably the first conflicts opinion dealing with the statute of frauds that did not so much as mention "substance" or "procedure." 105 After being comparatively neglected by the law reviews, ${ }^{100}$ the opinion was hailed as one of the four landmark cases of recent conflicts law. ${ }^{107}$ Its result, which upholds the oral contract under Nevada law, has achieved unanimous acceptance among conflicts scholars. And, although there is some disagreement as to which conflict of laws approach Traynor accepted as the basis of his opinion, ${ }^{108}$ the reasoning in Bernkrant has received the general approval it so plainly deserves.

I have very hittle to add to the discussion of this case. Like everyone else, I agree with the result. And, like Moffatt Hancock and the California Law Review commentator, ${ }^{109}$ I read the opinion as resting on Currie's governmental interest approach to conflict of laws. There is, however, one sentence in the opinion which I think deserves to be given its proper high place in conflict of laws methodology. It does not strain language too much to read almost the whole of modern conflicts thought into that one sentence of Traynor's in Bernkrant v. Fowler; it deserves to become the motto of a new edition of the Selected Readings on Confict of Laws. The sentence, following an introductory sentence necessary to make its sense plain, reads as follows:

The Legislature, however, is ordinarily concerned with enacting laws to govern purely local transactions, and it has not spelled out the extent to which the statute of frauds is to apply to a contract having substantial contacts with another state. Accordingly, we must

Some Notes on Bernkrant, in Perspectives of Law: Essays for Austin Warkeman Scott 38 (Pound, Griswold, Sutherland ed. 1964); Currie and Schreter (now Kay), supra note 103.

105 Currie, Justice Traynor and the Conflict of Laws, 13 Stan. L. Rev. 719, 778 n.236 (1961); Seuected Essays at 688-89.

106 The only law review comment on the case is that in 49 CALIF. L. REv. 962 (1961). 107 Baade, Foreword, 28 Law \& Contedra. Prob. 673, 673 n.4 (1963).

108 Hancock, In the Parish of St. Mary le Bow, in the Ward of Cheap, 16 STAN. L. Rev, 561, 627 n.213 (1964) states that California adopted the governmental interests approach in Bernkrant. The California Law Review Note agrees. 49 CarIF. L. Rev. 962, 963-65 (1961). But see Ehrenzweig, Choice of Law: Current Doctrine and "True Rules", 49 CALIF. L. REv. 240, 252 n.66 (1961): "The court's 'interest' language does not seem to add anything to its careful analysis of California policy." Traynor does refer to "the basic policy of . . . upholding contracts valid under the only law apparently applicable. . . "Bernkrant v. Fowler, 55 Cal. 2d 588, 594, 360 P.2d 906, 909, 12 Cal. Rptr. 266, 269 (1961).

109 Note, 49 CaIIF. L. REv. 962 (1961). 
determine its scope in the light of applicable principles of the law of conflict of laws."110

Thus is the interpretation of a local statute for the purposes of a conflicts case treated with the same care and sensitivity as that demanded for its interpretation in domestic cases; thus is the range of modern conflicts theory taken into account and given persuasive value as an aid to the elaboration of local policy; thus is outworn dogma discarded; thus does the forum begin a moderate definition of its own interests to exhaust all reasonable possibilities of avoiding a conflict with the defined policy of Nevada in a case where Nevada plainly has an interest in asserting her policy; thus, in short, does Roger Traynor approach a conflicts problem. If, in the course of his opinion, he handles the complexities of contemporary conflicts law so expertly that he leads some commentators to doubt that other judges will possess the skill to follow his lead, ${ }^{112}$ that fear itself is but another testimonial to Traynor's extraordinary achievements as a judge. Let us hope that Traynor sits long upon the bench and that many, unany more difficult conflicts problems find their way to California.

110 Bernkrant v. Fowler, 55 Cal. 2d 588, 594, 360 P.2d 906, 909, 12 Cal. Rptr. 266, 269 (1961). (Emphasis added.)

111 Note, 49 CaIrF. L. REv. 962, 968 (1961). 